\title{
STRENGTHENING OF THE ORAL EXPRESSION IN ENGLISH OF THE MEMBERS OF MUSHILY CULTURAL CENTER OF THE TSÁCHILAS NATIONALITY THROUGH PRACTICES FROM THE COMMUNICATIVE APPROACH ${ }^{\mathrm{i}}$
}

\author{
Kennedy Pinargote Rodriguez, \\ Jhonny Villafuerte-Holguin ${ }^{\text {ii }}$ \\ Research project: Comprensión Lectora y Escritura Académica \\ of the University Laica Eloy Alfaro of Manabí, \\ Research Network RED-LEA “Cambiando vidas"
}

Ecuador

\begin{abstract}
:
The present research aim is to determine the level of influence on the oral expression of English as a foreign language from the communicative approach. This work has a mixed (quail-quantitative) approach, not experimental. To achieve the objective of this research, the relationship between the variables was analyzed: oral expression of English and communicative approach in a population of 15 members of the Mushily Cultural Center of the Tsáchilas nationality. As research instruments, an interview form, a rubric was used to evaluate the part of oral expression. The data obtained were scored and using the excel program, the treatment and statistical analysis were carried out. Finally, it was concluded that the communicative approach has a significant relationship with the oral expression ability of the English language since when implemented in the teachinglearning process, favorable results were obtained.
\end{abstract}

Keywords: oral expression, communicative approach, skill, teaching, learning

\section{Resumen:}

El objetivo de la presente investigación fue determinar el nivel de influencia en la expresión oral del inglés como lengua extranjera desde el enfoque comunicativo. Este trabajo tiene un enfoque mixto (codorniz-cuantitativo), no experimental. Para lograr el objetivo de esta investigación se analizó la relación entre las variables: expresión oral del inglés y enfoque comunicativo en una población de 15 integrantes del Centro Cultural Mushily de la nacionalidad Tsáchilas. Como instrumentos de investigación se utilizó un

\footnotetext{
i FORTALECIMIENTO DE LA EXPRESIÓN ORAL EN INGLÉS DE LOS INTEGRANTES DEL CENTRO CULTURAL MUSHILY DE LA NACIONALIDAD TSÁCHILAS A TRAVÉS DE PRÁCTICAS DESDE EL ENFOQUE COMUNICATIVO

ii Correspondence: email jhonny.villafuerte@gmail.com
} 
formulario de entrevista, una rúbrica para evaluar la parte de expresión oral. Los datos obtenidos fueron puntuados y mediante el programa excel se realizó el tratamiento y análisis estadístico. Finalmente se concluyó que el enfoque comunicativo tiene una relación significativa con la habilidad de expresión oral del idioma inglés ya que al implementarlo en el proceso de enseñanza aprendizaje se obtuvieron resultados favorables.

Palabras clave: expresión oral, enfoque comunicativo, destreza, enseñanza, aprendizaje

\section{Introduction}

To talk about the human being is to understand it as a social and communicative being, because people are born, grow, and form within social groups and institutions such as family, school, and friends. Sometimes, human being can act individually. But most of the time, it does so subject to a series of conditions of its context and of the people who are there. As stated by Lera (2016), "the human being must act collectively so that basic social processes, such as communicating, allow him to survive" (p. 11). Therefore, the need to strengthen the communicative dimension becomes evident, since it is a process that allows the human being to carry out these social roles, which will be fundamental for their survival and sociocultural interaction.

For this to be carried out successfully, it is necessary that there be, on the one hand, a medium such as a language, which allows the human being to designate the objects of the external world, their actions, their qualities, and the relationships between their peers. On the other hand, you need a tool, that is, the language, that allows you to materialize these designs and help you to establish a communication network with your peers in which you can express your thoughts, your ideas, your emotions, your feelings, and everything that through the language it is possible to communicate.

Teaching English as a foreign language can be fun and meaningful when teachers apply engaged activities in their classrooms. Children will feel motivated and participate by interacting with others with enthusiasm. These activities can encourage student participation by contributing to improving their oral and auditory production of the English language (Macias, 2017).

Today, more and more people in Ecuador and the world are becoming interested in learning the English language. This demand is caused by the possibility of travelling around the world, globalization, business issues, work requirements and cultural awareness of other countries.

The project aims to improve the English oral expression of the members of the Mushily cultural center of the Tsáchilas nationality, from the communicative approach, trying to apply as far as possible the techniques and tools acquired in my training as a future professional in a foreign language (English). 


\section{Theoretical Framework}

\subsection{Speaking in English as a Foreign Language}

For many students, the spoken skill is usually the most difficult language aspect to handle in a target language since you not only need to know what to say but also understand it for there to be good communication. Martínez (2016) cites that Baralo defines oral expression as a skill with interaction and bidirectionality in a situation in which meanings are negotiated and that does not make sense without the understanding or interpretation of what has been heard.

It is this that differentiates human beings from the rest of the living beings of nature since it is an innate particularity of man since we are owners of intelligence and reason.

Martinez (2016) describes oral expression as a systematic process that includes cognitive aspects ranging from attentive listening to the observation and reflection of a response that is the result of language interaction. That is why we can describe what surrounds us, what happens to us, inform (spontaneous oral expression) as well as express our emotions and thoughts (reflective oral expression) and thus achieve effective communication.

Macías (2017) refers that oral expression is a linguistic skill that develops communicative competence where the speaker must think about what to say and say clearly turning it into a complex activity. Likewise, Granda (2017) cites Thornbury who considers that oral expression is deeply linked to understanding.

Considering the above definitions, it is suggested to keep these concepts in mind in the class sessions. Ruiz (2010) states that the supra-objective of language classes is to develop communicative skills and that the role of these is to teach to speak in a situation, even if the conversations are not so specific but to consider general aspects that must be had, to issue sequences in the amount that is required, that they are relevant and have a good structure.

Alata, Garcia \& Mercedes (2018) mention that it is necessary to contribute to the strengthening of the target language in the following aspects: correct articulation, fluency, adequate intonation, adequate use of gestures and mimicry, capacity for persuasion and clear expression of ideas.

Reyes (2019) quotes Moreno who emphasizes that oral production must have the following aspects:

- Fluency, this must be continuous without interruptions or some type of serious stop at the time of articulating the words, that is, it produces communicative orality in a practical and original way.

- Grammatical and lexical richness, this aspect is taken as complex since it is where the use of grammatical structures, discursive, vocabulary, etc. are found. The use of these elements makes oral expression better appreciated, of course, which must be adapted in a progressive way 
- Phonic level, is the communicative dimension that includes the intonation, pauses, sharpness and pronunciation of good communicative production.

- That is why, by getting people to develop good oral expression skills, they would also develop communicative competence. For this reason, teachers must facilitate various activities that motivate them to practice, improve their pronunciation and that goes hand in hand with the vocabulary they are learning and the grammatical structures they are developing.

Bautista (2021) highlights that, in the process of natural language acquisition, oral expression is linked to listening comprehension, that is, it begins to speak naturally, receiving input. In this sense, speaking requires a process of prior listening. It also mentions that the teaching of a second language must consider several aspects, so the language can be divided into three levels: morphological, phonological, and syntactic.

In foreign language teaching, the oral expression has as a formal objective that the student can express himself orally effectively considering communication as a transfer of relevant information to the recipient. Oral expression starts from the communicative approach, being necessary the practice of communicative tasks. The nature of oral expression, in terms of its linguistic manifestation, consists of three components: lexical, morphosyntactic and phonological. As for its own configuration are interactive discourses, extralinguistic components (communication strategies, gestures, and proximity), and psycholinguistic limitations (memory and anxiety). Oral expression is conceived as interactive communication, so the simplest form of communication would be a conversation where characteristics such as time to prepare what is said, the creation of an interactive discourse, the dependence on the feedback provided by the interlocutor, the use of a non-verbal language, among others.

The didactics of oral expression considers a series of steps such as providing models, performing exercises oriented to the formal practice of elements necessary for communication: lexicons, morphosyntactic and phonological. It is necessary to perform motivating activities to practice the functions involved in the speech acts necessary for the intended communication object and to carry out meaningful activities and tasks.

The development of oral skills in the English language finds with the communicative approach its full progress. In this regard, Wade (2016) believes that oral competence can occur completely in this model through interaction and in various contexts. This approach emphasizes communicative competence, defined as the ability to produce language in a situational and socially acceptable way; in other words, it is the ability to know what to say, how to speak or to whom, when, how to do it and about what (Rico-Yate \& Ramírez-Montoya, 2016).

It is necessary to develop confidence in the learner so that he is encouraged to actively participate in the constant oral interaction required to develop communicative competence. Hadaway \& Young (2016) point out the need to create a comfortable learning environment in the English classroom. Also, Chen \& Goh (2016) argue that greater importance should be given to the improvement of oral production skills through 
an effective curriculum that involves oral instruction in its design. This will facilitate the promotion of students' English communication skills so that they make use of the language in real contexts and situations.

The development of oral competence in English requires special strategies for its promotion. Speaking skills need a series of communicative learning activities, such as completing empty spaces, games, puzzles, problem-solving, performances, among others. A plausible way to achieve students' communicative competence is homework, as it provokes in the student a need to communicate and create meanings. Another strategy is to use thinking-aloud as a technique by which the individual orally expresses his thoughts during the exercise of his reading activity. This technique contributes to improving the cognitive processes of the learner and allows him to connect meanings and understandings with the text. Thus, the exploration and application of various strategies for the development of oral ability by the English teacher help the student to communicate in the language more naturally.

\subsection{The Communicative Approach}

The methods are rigid structures that have been used in the teaching of foreign languages, especially in the teaching of the English language. For this reason, it is appropriate to speak of approaches from a somewhat more flexible perspective in the didactics of foreign languages.

Education has been constantly evolving. That is why, today, teaching must be focused on the real needs of the student. The same goes for this methodology for teaching foreign languages, also known as the communicative approach. This methodology uses a didactic proposal for the teaching of languages that has as its main objective, the improvement of the communicative competence of the students, in real situations.

The communicative approach is closely linked to the ideal method of teaching and learning proposed by Psycholinguistics, which focuses on the real speaker and not on the ideal speaker, just as the communicative approach does. Sánchez (2009) states: "The purpose of teaching foreign languages is that students are able to act naturally in real contexts. It is therefore about teaching students to become unlimited speakers."

This method has taken on great relevance in the development of strategies to address speech and listening within classrooms and in the contexts where you want to teach a foreign language. Palacios (2012) ratifies the above: "the communicative approach is a didactic proposal for the teaching of languages and literature, which underlines as an essential objective of this linguistic and literary education the improvement of this communicative competence of students, that is, their ability to understand and produce adequate statements with diverse communication intentions in heterogeneous communicative contexts."

This is how this methodological proposal focuses its fundamental axis, of learning, teaching foreign languages, on the development of communicative skills. These should not only be put in the classroom but should be meaningful so that in turn they can be applied within real-life situations. 
In this way, using this methodology within the classroom will give an extraordinary value to language and communication. In addition, the communicative approach is of great relevance within the classroom, because it is in this place where the first natural social interactions of students occur using certain linguistic resources, these resources can be taken beyond the classroom and be used in a daily context.

The Communicative Approach in the teaching of a language starts from the following idea: "Language is communication", therefore, the goal of language teaching will always be to achieve communicative competence. According to Hymes, quoted by Cook (2017), "a person who had only linguistic competence would be quite unable to communicate". That is, producing grammatically sentences disconnected from real situations does not guarantee to have communicative competence. This communicative competence implies other competencies, such as socio-linguistic, discursive, and strategic skills. By way of illustration, the latter refers to the strategies that participants employ to initiate, terminate, maintain, correct, and redirect communication.

The Communicative Approach aims to give greater relevance to the interactive processes of communication between teachers, participants, and peers. Here the teacher facilitates the communication process between all participants; acts as an independent participant within the teaching-learning group; the student, on the other hand, brings his own ideas of what teaching-learning should be like. The teacher investigates, analyzes the linguistic needs of the student, advises, and manages the learning process in the group.

The Communicative Language Learning approach aims to reduce the anxiety of the student, who at some point may show problems in the production of language. It is there that the teacher creates a warm situation of guidance and resolution of linguistic conflicts, providing the student with greater security and progressive confidence in their abilities.

The communicative approach has the following characteristics:

- Through language it is always about saying "something to someone" and this can be orally or written.

- The content to share is the important thing.

- To facilitate the understanding of messages, the communicative process must take place within a situation or context.

- Using extralinguistic elements, the exchange of information is carried out and this is initiated by an interest of those involved in the communication process.

- It is important that those involved attend to the established code, that is, grammar, which is a means to achieve communicative ends. (Baptist, 2021)

The principles on which the communicative approach is based are:

- Language is used since it is the system used by human beings to be able to communicate based on the exchange of content but not on the form.

- It is not only limited to linguistic or grammatical competence since the result of several competences is communicative competence. 
- It focuses on primary communication, i.e., oral, and everyday situations.

- Thinking has an important role in this process, which is why it is not only based on repetitions.

- The content of the message is important to the interlocutors, which is why it is said that language learning focuses on a relevant framework.

- The teacher's job is to guide, organize, advise, and create ideal conditions for students to learn and create their own knowledge about what they already have.

- The main protagonist and active agent of greatest importance is the student.

- Class sessions must be participatory.

- The materials to be used are varied and representative of reality.

$\circ$ The error is tolerated to a fair extent since it is something natural in the learning process.

The main objective of this approach is the student since he must have the ability to communicate effectively in the target language using linguistic aspects to communicate in real-life situations, that is, in a relevant communicative context (sociolinguistic competence). What is sought is to acquire the skills that make up the grammar-communicative competence to achieve complete and total learning ensuring that there is communication. It is important to mention that the class session is organized with interactive participation criteria, especially oral interaction because in this way the student will learn the vocabulary that is needed in the different contexts that can be presented.

\section{Research Questions}

- How can the communicative approach be adapted in strengthening the oral expression of English of the members of the Mushily Cultural Center of the Tsáchila nationality?

- Is the level of oral expression adequate?

- How is it possible to monitor the progress of participants in the acquisition of EFL?

- What is the level of satisfaction and motivation of the members of the Mushily Cultural Center of the Tsáchila nationality in the English learning classes?

- Is the communicative approach important to strengthen the oral expression of the members of the Mushily Cultural Center of the Tsáchila nationality?

This research aim is to determine the level of influence on the oral expression of English as a foreign language from the communicative approach.

\section{Methodology}

This work adheres to the socio-critical paradigm. The research is oriented towards a mixed, i.e., quail-quantitative approaches. Mixed research is a research methodology that consists of collecting, analyzing, and integrating both quantitative and qualitative 
research. Quantitative data includes closed information such as that used to measure attitudes, for example, scoring scales. The analysis of this type of data consists of statistically analyzing the scores collected, for example, through surveys, to answer research questions. Qualitative data are open information that the researcher usually collects through interviews, discussion groups and observations. The analysis of qualitative data (words, texts, or behaviors) usually consists of separating them by categories to know the diversity of ideas gathered during data collection (Sampieri, 2016).

The study has also indicated that a mixed methodology design leads the researcher to a better understanding of the research problem.

The participants of this project are 15 native members of the Tsáchilas nationality, who are dedicated to many activities to subsist among the most relevant are touristic activities where they make known their culture, traditions, and ancestral customs to national and foreign visitors.

\subsection{Instruments}

The instruments used to collect data were the rubric for spoken skill, lesson plans, interview, observation records.

The lesson plans. It was based on specific content of the Ecuadorian Curriculum for English language Instruction. It is a collection of 12 sessions of 60 minutes each one. It considered the communicative approach to the teaching of English as a foreign language. In addition, they were modified for the needs of the class and required instructor produce didactic material for supporting the explanation during the sessions.

The rubric for spoken skill evaluation. It used the Cambridge Press format for speaking evaluation. The instrument used included four criteria: pronunciation, intonation, fluency, and accuracy. The instrument was used before (pretest) and after (pos test) following the respective procedures. The rubric was evaluated by three English as a foreign language instructor.

The interview forms. It has five clear and easy questions for the Director of the Cultural Center, and they are about many requirements about learning English. The instrument was evaluated by experts' panel integrated for professional affiliated to an Ecuadorian university. Their recommendations were to reduce the number of 12 questions from the original version to 5 questions.

\section{Results}

\subsection{Interview with the Director of the Mushily Cultural Center:}

The interview had as goal to collect information about the participants' motivations for learning English as a foreign language.

1. Do people in the community have access to learning new languages by state institutions? 
A: "As for access to learning a new language within the community is null because the Ministry of Education does not provide English texts to our children, but it does not give us the availability of an English teacher to teach or guide our children in that subject."

2. Do you think it is necessary to learn a foreign language within your community? A: "My answer is yes, more than necessary because we receive the visit of people from other countries and the English language is very necessary to be able to communicate with them."

3. Do you consider the presence of an English teacher necessary in schools in your community?

A: "If I consider that having an English teacher in our cultural center will be very important because then we will learn a new language and they will be able to transmit our customs and traditions more effectively than we parents do today."

4. What do you think are the most important points to learn about the English language?

A: "What we need the adults and tour guides of the cultural center is to learn to say hello, to say the names of our products to offer to foreign tourists, and children can learn more things since they have more time than us adults and it is less difficult for them to learn any subject."

5. How do you like to carry out this project in your community?

A: "From my point of view, I can say as representatives of all the members of the cultural center that we are very happy with the initiative you have with us. because it helps us a lot in our activities and to see the abandonment of the authorities who only visit us when they want to take a photo for him but to support us or train us, we are abandoned so we congratulate their initiative with this project."

Source: Anonymous interview (March /2020).

\subsection{Interview Analysis}

The interview with the director of the Mushily Cultural Center allows us to establish that there are limitations in terms of resources to be able to access learning English, in addition to the urgent need to acquire skills in this language due to the tourist activities they carry out, for which they express the predisposition of the proposal presented by the author of the research as well as to provide the necessary facilities.

\subsection{Participants English Language Knowledge}

In the Table 1 are presented the pretest results. 


\begin{tabular}{|c|c|c|c|}
\hline Aspect & $\begin{array}{l}\text { Have the knowledge } \\
\text { to transmit ideas } \\
\text { in English }\end{array}$ & $\begin{array}{c}\text { Do not have the knowledge } \\
\text { to transmit ideas } \\
\text { in English }\end{array}$ & Total \\
\hline \multicolumn{4}{|l|}{ Pronunciation } \\
\hline $\begin{array}{l}\text { 1. Clear and correct pronunciation } \\
\text { intonation }\end{array}$ & $1(7 \%)$ & $14(93 \%)$ & 15 \\
\hline $\begin{array}{l}\text { 2. Volume appropriate to the } \\
\text { situation }\end{array}$ & $1(7 \%)$ & $14(93 \%)$ & 15 \\
\hline $\begin{array}{l}\text { 3. Natural and enjoyable } \\
\text { intonation }\end{array}$ & $1(7 \%)$ & $14(93 \%)$ & 15 \\
\hline $\begin{array}{l}\text { 4. Always speak with clarity and } \\
\text { distinction }\end{array}$ & $1(7 \%)$ & $14(93 \%)$ & 15 \\
\hline \multicolumn{4}{|l|}{ Accuracy } \\
\hline $\begin{array}{l}\text { 5. It emits little errors in the } \\
\text { use of learned structures. }\end{array}$ & $1(7 \%)$ & $14(93 \%)$ & 15 \\
\hline $\begin{array}{l}\text { 6. The exhibition presents a few } \\
\text { errors in the use of learned } \\
\text { structures. }\end{array}$ & $1(7 \%)$ & $14(93 \%)$ & 15 \\
\hline $\begin{array}{l}\text { 7. The examples are precise and } \\
\text { appropriate to the topic } \\
\text { addressed }\end{array}$ & $1(7 \%)$ & $14(93 \%)$ & 15 \\
\hline $\begin{array}{l}\text { 8. Shows a complete } \\
\text { understanding of the phrases of } \\
\text { the conversation. }\end{array}$ & $1(7 \%)$ & $14(93 \%)$ & 15 \\
\hline \multicolumn{4}{|l|}{ Fluency } \\
\hline $\begin{array}{l}\text { 9. The sentences follow a logical } \\
\text { order so that the message is } \\
\text { understandable. }\end{array}$ & $1(7 \%)$ & $14(93 \%)$ & 15 \\
\hline $\begin{array}{l}\text { 10. The interlocutor seems totally } \\
\text { relaxed and presents himself } \\
\text { naturally }\end{array}$ & $1(7 \%)$ & $14(93 \%)$ & 15 \\
\hline
\end{tabular}

Source: Participants' records.

As can be established in this pre-test, $93 \%$ of the people to whom this instrument was applied, do not have communicative skills in English, as they have low levels of pronunciation, intonation, accuracy, and fluency. Only $7 \%$ of the total has a certain level of language skill due to their self-preparation.

Next, the respective class plans that were implemented with the people of the Mushily Cultural Center are established, adapting them to the requirements of the participants, in an adequate and pedagogically motivating environment.

\subsection{Lesson Plans}

The lesson plans executed in this research are presented following. 
Kennedy Pinargote Rodriguez, Jhonny Villafuerte-Holguin

STRENGTHENING OF THE ORAL EXPRESSION IN ENGLISH OF

THE MEMBERS OF MUSHILY CULTURAL CENTER OF THE TSÁCHILAS

NATIONALITY THROUGH PRACTICES FROM THE COMMUNICATIVE APPROACH

\begin{tabular}{|c|c|}
\hline Resources/Materials & Lesson Objectives \\
\hline $\begin{array}{l}{ }^{*} \text { Bookmarks } \\
{ }^{*} \text { Notebooks. } \\
{ }^{*} \text { Pencils. } \\
{ }^{*} \text { Drafts. }\end{array}$ & $\begin{array}{l}\text { At the end of the lesson, students will be able to create a paragraph about } \\
\text { introducing themselves and answering questions about personal information. }\end{array}$ \\
\hline \multicolumn{2}{|c|}{ Warm-up and Objective Discussion } \\
\hline \multicolumn{2}{|c|}{$\begin{array}{l}\text { *Greet the students, and I will explain what the lesson will be about. } \\
\text { *I started the class speaking entirely in English to introduce myself, then explained the reasons why I } \\
\text { did this. I did this to motivate them, I told them that at the end of the course I want them to speak } \\
\text { fluently and completely in English. }\end{array}$} \\
\hline \multicolumn{2}{|l|}{$\begin{array}{l}\text { Learning Activity } \\
\text { (Guided Practice) }\end{array}$} \\
\hline \multicolumn{2}{|c|}{$\begin{array}{l}{ }^{*} \text { I explained how to ask and answer questions about personal information, wrote the Spelling in } \\
\text { English, the pronunciation, and the Spanish translation of the questions given. } \\
\text { *Taught basic questions to ask personal information for example, what is your name? How old are } \\
\text { you? Where are you from? Where do you live? } \\
\text { *They were taught how to answer the above questions. }\end{array}$} \\
\hline
\end{tabular}

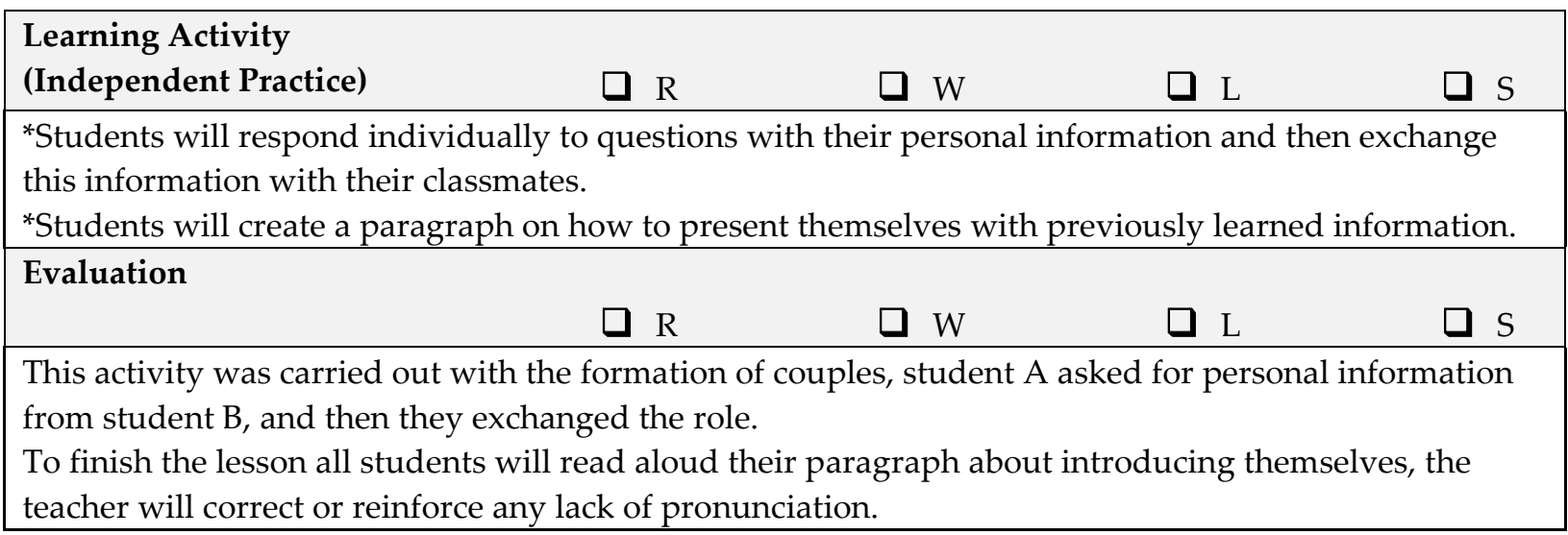

Class 2: Presentation

\begin{tabular}{|c|c|}
\hline Resources/Materials & Lesson Objectives \\
\hline $\begin{array}{l}{ }^{*} \text { Bookmarks } \\
\text { *Notebooks. } \\
\text { *Pencils. } \\
\text { *Drafts. }\end{array}$ & $\begin{array}{l}\text { At the end of the lesson, students will be able to use numbers in any } \\
\text { context they can be given. }\end{array}$ \\
\hline \multicolumn{2}{|c|}{ Warm-up and Objective Discussion } \\
\hline \multicolumn{2}{|c|}{$\begin{array}{l}\text { *Greet the students, and I will explain what the lesson will be about. } \\
\text { *I started the class by graduating the use of the foreign language so that they do not get frustrated. } \\
\text { *I told them my age, the price my phone bought, and more examples, to show them in what context. } \\
\text { numbers are used and the importance of learning those in English. }\end{array}$} \\
\hline $\begin{array}{l}\text { Learning Activity } \\
\text { (Guided Practice) }\end{array}$ & $\square \mathrm{W}$ \\
\hline
\end{tabular}




\begin{tabular}{|c|c|c|c|c|}
\hline $\begin{array}{l}\text { Learning Activity } \\
\text { (Independent Practice) }\end{array}$ & $\square \mathrm{R}$ & 口 W & $\square \mathrm{L}$ & a \\
\hline \multicolumn{5}{|c|}{$\begin{array}{l}\text { Students will use the numbers in any context they wish, some of them decided to use the numbers to say } \\
\text { their age, some of them to say the praise of some objects. }\end{array}$} \\
\hline \multicolumn{5}{|l|}{ Evaluation } \\
\hline & $\mathrm{R}$ & $\square \mathrm{W}$ & $\square \mathrm{L}$ & $\square s$ \\
\hline
\end{tabular}

Class 3: Costs

\begin{tabular}{|l|l|}
\hline Resources/Materials & \multicolumn{1}{c|}{ Lesson Objectives } \\
\hline${ }^{*}$ Bookmarks & At the end of the lesson, students will be able to answer some questions \\
*Notebooks. & about the cost of some products they offer to tourists. \\
*Pencils. & \\
$\begin{array}{l}\text { *Drafts. } \\
\text { *Craftsmanship. }\end{array}$ & \\
\hline
\end{tabular}

Warm-up and Objective Discussion

${ }^{*}$ Greet the students, and I will explain what the lesson will be about.

*I explained the importance of learning to answer questions in English about the prices of the products they offer.

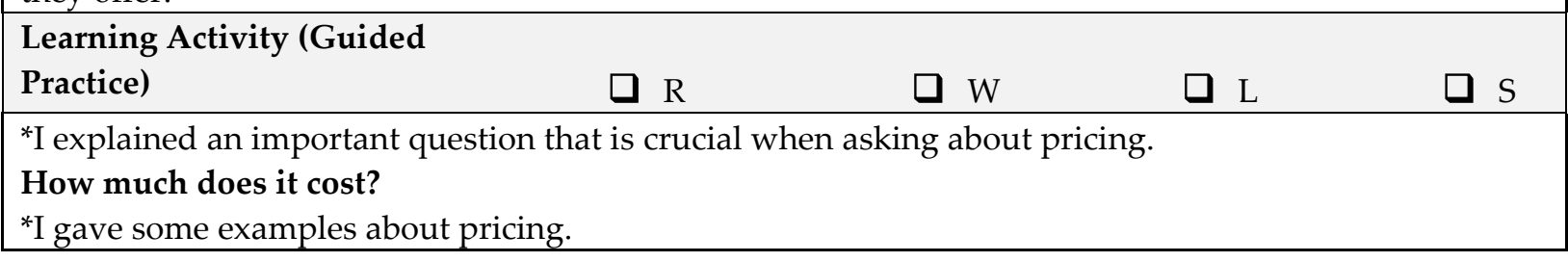

Learning Activity

(Independent Practice)

$\mathrm{R}$

$\mathrm{W}$

口 L

$\square \mathrm{S}$

*Students will write some questions with how much does it cost? but including some products they offer to visitors.

${ }^{*}$ They included objects such as their handicrafts: bracelets, key chains, chains.

\section{Evaluation}

\section{$R$}

*At the end of the lesson the teacher asks the price of some objects offered to visitors.

*They will play a role play, student A asks about prices and student $B$ answers, then exchange.

The teacher is constantly correcting the pronunciation.

Class 4: Nationalities

\begin{tabular}{|c|c|}
\hline Resources/Materials & Lesson Objectives \\
\hline $\begin{array}{l}{ }^{*} \text { Bookmarks. } \\
{ }^{*} \text { Notebooks. } \\
{ }^{*} \text { Pencils. } \\
{ }^{*} \text { Drafts. } \\
{ }^{*} \text { Cut pieces of paper. }\end{array}$ & $\begin{array}{l}\text { At the end of the lesson, students will be able to ask and answer } \\
\text { questions about nationalities. }\end{array}$ \\
\hline
\end{tabular}


*I explained how important it is to learn the nationalities, because they receive many foreign visitors, and this could be important to know where they are from to have a better interaction and visitors have a good impression of them.

\section{Learning Activity}

(Guided Practice)

*I will teach you the English spelling of the most common countries around the world.

*I will teach you the nationality of the countries taught above.

*Each part contains the respective pronunciation practice.

\section{Learning Activity}

(Independent Practice)

$\square \mathrm{R}$

$\square \mathrm{W}$

$\square \mathrm{L}$

*Students will choose a small document containing a country.

*Students will write a paragraph about their personal information including the nationality of the chosen country.

\section{Evaluation}

*To evaluate students, they will speak aloud the paragraph about their personal information, including nationality.

*They will ask the nationality of the chosen country to any of their colleagues.

Class 5: Communicative Phrases

\begin{tabular}{|c|c|}
\hline Resources/Materials & Lesson Objectives \\
\hline $\begin{array}{l}{ }^{*} \text { Bookmarks. } \\
{ }^{*} \text { Notebooks. } \\
\text { *Pencils. } \\
\text { *Drafts. }\end{array}$ & $\begin{array}{l}\text { At the end of the lesson, students will be able to use a few daily } \\
\text { communicative phrases at the time of receiving a foreign visitor. }\end{array}$ \\
\hline \multicolumn{2}{|c|}{ Warm-up and Objective Discussion } \\
\hline \multicolumn{2}{|c|}{$\begin{array}{l}{ }^{*} \text { Greet the students, and I will explain what the lesson will be about. } \\
\text { *I explained how important it is to know basic phrases of the day to day, how useful it could be when } \\
\text { interacting with a foreign person. }\end{array}$} \\
\hline $\begin{array}{l}\text { Learning Activity } \\
\text { (Guided Practice) }\end{array}$ & $\square \mathrm{W}$ \\
\hline
\end{tabular}

Learning Activity

(Independent Practice)

a $\mathrm{R}$ W $\mathrm{L}$

*Students will create a small paragraph using the basic daily communicative phrases.

Evaluation
$\square \mathrm{R}$
$\square \mathrm{W}$
$\mathrm{L}$

${ }^{*}$ To evaluate students, they will interact in pairs, student A will be a foreign person, and student B will be a local person.

*Student B will welcome student A, then exchange roles. 


\begin{tabular}{|c|c|}
\hline Resources/Materials & Lesson Objectives \\
\hline $\begin{array}{l}{ }^{*} \text { Computer. } \\
{ }^{*} \text { Notebooks. } \\
{ }^{*} \text { Pens. }\end{array}$ & $\begin{array}{l}\text { At the end of the lesson, the student will create a paragraph describing all } \\
\text { the activities to which he is engaged, and how to transmit it to a foreign } \\
\text { person. }\end{array}$ \\
\hline \multicolumn{2}{|c|}{ Warm-up and Objective Discussion } \\
\hline \multicolumn{2}{|c|}{$\begin{array}{l}{ }^{*} \text { Greet the students, and I will explain what the lesson will be about. } \\
\text { *They asked me to help them create a paragraph to convey their activities to visitors. } \\
\text { *This session was held virtually. }\end{array}$} \\
\hline $\begin{array}{l}\text { Learning Activity } \\
\text { (Guided Practice) }\end{array}$ & $\square \mathrm{W}$ \\
\hline
\end{tabular}

Learning Activity

(Independent Practice)

a $\mathrm{R}$

$\square \mathrm{W}$

$\mathrm{L}$

S

Students will create a short paragraph stating their personal information, their daily activities in their community, and how to welcome a foreign person. They will have 20 minutes to finish, the teacher is all the time answering questions.

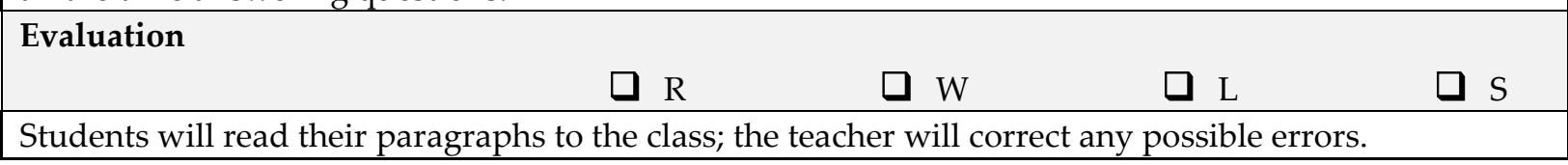

Table 3: Participants' English Knowledge Evaluation in Pre-test

\begin{tabular}{|l|c|c|c|c|c|c|c|}
\hline \multirow{2}{*}{ Class } & $\mathbf{1}$ & \multirow{2}{*}{$\%$} & $\mathbf{2}$ & \multirow{2}{*}{$\%$} & $\mathbf{3}$ & \multirow{2}{*}{$\%$} & \multirow{2}{*}{ Total } \\
\cline { 2 - 3 } & Acceptable & & Suitable & & Insufficiency & & \\
\hline Class 1. Introducing yourself & 3 & $20 \%$ & 10 & $67 \%$ & 2 & $13 \%$ & 15 \\
\hline Class 2. Numbers & 3 & $20 \%$ & 10 & $67 \%$ & 2 & $13 \%$ & 15 \\
\hline Class 3. Costs & 3 & $20 \%$ & 10 & $67 \%$ & 2 & $13 \%$ & 15 \\
\hline Class 4. Nationalities & 3 & $20 \%$ & 10 & $67 \%$ & 2 & $13 \%$ & 15 \\
\hline Class 5. Communicative phrases & 3 & $20 \%$ & 10 & $67 \%$ & 2 & $13 \%$ & 15 \\
\hline Class 6. Welcome & 3 & $20 \%$ & 10 & & 2 & $13 \%$ & 15 \\
\hline
\end{tabular}

Source: Participants' evaluation prestest.

The evaluation results applied to the different classes taught through the communicative approach to members of the Mushily Cultural Center can be established that there is a considerable percentage $(67 \%)$ that is at adequate levels, noting that the methodology applied has obtained favorable results. There is a percentage of $20 \%$ who are at satisfactory levels and a percentage of $13 \%$ who need to reinforce knowledge and practice to raise their level. 


\subsection{Participants' English Language Knowledge Post-test Results}

Table 4: Participants' English Knowledge Evaluation in Post-test

\begin{tabular}{|c|c|c|c|}
\hline Aspect & $\begin{array}{c}\text { Have the knowledge } \\
\text { to transmit ideas } \\
\text { in English }\end{array}$ & $\begin{array}{c}\text { Do not have the } \\
\text { knowledge to transmit } \\
\text { ideas in English } \\
\end{array}$ & $\begin{array}{c}\begin{array}{c}\text { Total } \\
\text { of } \\
\text { participants }\end{array} \\
\end{array}$ \\
\hline \multicolumn{4}{|l|}{ Pronunciation } \\
\hline $\begin{array}{l}\text { 1. Clear and correct } \\
\text { pronunciation }\end{array}$ & $13(87 \%)$ & $2(13 \%)$ & 15 \\
\hline \multicolumn{4}{|l|}{ Intonation } \\
\hline $\begin{array}{l}\text { 2. Volume appropriate to the } \\
\text { situation }\end{array}$ & $13(87 \%)$ & $2(13 \%)$ & 15 \\
\hline $\begin{array}{l}\text { 3. Natural and enjoyable } \\
\text { intonation }\end{array}$ & $13(87 \%)$ & $2(13 \%)$ & 15 \\
\hline $\begin{array}{l}\text { 4. Always Speak with clarity } \\
\text { and distinction }\end{array}$ & $13(87 \%)$ & $2(13 \%)$ & 15 \\
\hline \multicolumn{4}{|l|}{ Accuracy } \\
\hline $\begin{array}{l}\text { 5. It emits little errors in the } \\
\text { use of learned structures. }\end{array}$ & $13(87 \%)$ & $2(13 \%)$ & 15 \\
\hline $\begin{array}{l}\text { 6. The exhibition presents } \\
\text { few errors in the use of } \\
\text { learned structures. }\end{array}$ & $13(87 \%)$ & $2(13 \%)$ & 15 \\
\hline $\begin{array}{l}\text { 7. The examples are precise } \\
\text { and appropriate to the topic } \\
\text { addressed }\end{array}$ & $13(87 \%)$ & $2(13 \%)$ & 15 \\
\hline $\begin{array}{l}\text { 8. Shows a complete } \\
\text { understanding of the phrases } \\
\text { of the conversation. }\end{array}$ & $13(87 \%)$ & $2(13 \%)$ & 15 \\
\hline \multicolumn{4}{|l|}{ Fluency } \\
\hline $\begin{array}{l}\text { 9. The sentences follow a } \\
\text { logical order so that the } \\
\text { message is understandable. }\end{array}$ & $13(87 \%)$ & $2(13 \%)$ & 15 \\
\hline $\begin{array}{l}\text { 10. The interlocutor seems } \\
\text { totally relaxed and presents } \\
\text { himself naturally. }\end{array}$ & $13(87 \%)$ & $2(13 \%)$ & 15 \\
\hline
\end{tabular}

Source: Participants' evaluation prestest.

In the rubric of progress, it can also be seen that there is an improvement of verbal communication skills in English in the members of the Tsáchila Mushily Cultural Center, after applying the communicative approach in the verbal expression of English, as a tool that will allow them a socio-economic development of the tourist activity they carry out. It is also established that a percentage of $13 \%$ need to carry out reinforcement activities in terms of their learning process. 


\subsection{Discussion}

Based on the literature review, this research authors find coincidence with the position of Macías (2017) and Granda (2017) when they affirm that communicative approach is the most used in language learning currently, also known as the communicative approach. In this method, language is not presented as a system but as a means that promotes communication, for this reason, the communicative process is emphasized in the way linguistic structures are put into operation through human communication. The purpose of teaching through this approach must develop communicative competence and that this is part of the communicative approach. In the case of research, the communicative approach allows members of the Tsáchila Mushily Cultural Center to inform tourists who visit them about their customs, cultures, and exchange ideas. For this, it is necessary to obtain the verbal communication skills of English, which has been achieved in $87 \%$.

For many people, verbal communication in English is usually the most difficult skill to achieve in a target language, since you not only need to know what to say but also understand it for there to be good communication.

Martinez (2016) cites that Baralo defines oral expression as a skill with interaction and bidirectionality in a situation in which meanings are negotiated and that does not make sense without the understanding or interpretation of what has been heard. And the author continues to state that oral expression is a systematic process in which cognitive aspects are included that range from attentive listening to the observation and reflection of a response that is the result of language interaction. Due to this process, you can describe the environment, inform (spontaneous oral expression) as well as express emotions and thoughts (reflective oral expression) and thus achieve effective communication. Around the research carried out, $87 \%$ of the members of the Tsáchila Mushily Cultural Center have developed this skill at levels that allow them to communicate properly.

To close this work up, this can be done by answering the questions asked at the beginning of the process.

How can the communicative approach be adapted in strengthening the oral expression of English of the members of the Mushily Cultural Center of the Tsáchila nationality? The communicative approach can be adapted to the communicative approach in strengthening the oral expression of English of the members of the Mushily Cultural Center of the Tsáchila nationality according to their needs to inform about their customs and to maintain a conversation with tourists.

Is the level of oral expression adequate? The diagnosis allowed to establish that they did not have an adequate level of oral expression, it improved after the classes were implemented under the communicative approach.

How is it possible to monitor the progress of participants in the acquisition of EFL? It can be monitored by regular evaluations and observation sheets. 
What is the level of satisfaction and motivation of the members of the Mushily Cultural Center of the Tsáchila nationality in the English learning classes? There is a high level of satisfaction and motivation of the members of the Mushily Cultural Center of the Tsáchila nationality in the English learning classes.

Is the communicative approach important to strengthen the oral expression of the members of the Mushily Cultural Center of the Tsáchila nationality? Currently, where knowledge of the English language is relevant, the communicative approach has an important role as a teaching-learning methodology, in order to ensure that the members of the Tsáchila Mushily Cultural Center develop the ability of oral expression of this language, so it is also recommended, the use of English in their daily activities, strengthening fluency and reaching an expected standard of English language.

\section{Conclusions}

Based on the review of the literature and the results obtained in the empirical part of this study, the authors of this work declare that the proposed objective has been fully achieved. Therefore, $100 \%$ of the participants report an improvement in their vocabulary acquisition in English as a foreign language (EFL). The main contribution of this study is the exploration of a work process with a minority community such as the Mushily Cultural Center of the Tsáchila nationality. This is a creative contribution focused on oral communication but also on the motivation of the participants to learn EFL. The weakness of this research is the size of the corpus, which does not allow generalizations to be made. However, the results of this research offer didactic routes based on the communicative approach that can be developed in other similar processes. The scientific community is invited to propose new research projects aimed at the care of minority communities linked to the teaching and learning of English as a foreign language.

\section{Acknowledgements}

This work is subscribed to the project "Comprensión lectora y escritura académica of the University Laica Eloy Alfaro de Manabí, Ecuador. In addition, this work is also supported for the Researchers Network RED-LEA: "Cambiando vidas"

\section{Conflict of Interest Statement}

The authors declare no conflicts of interest. 


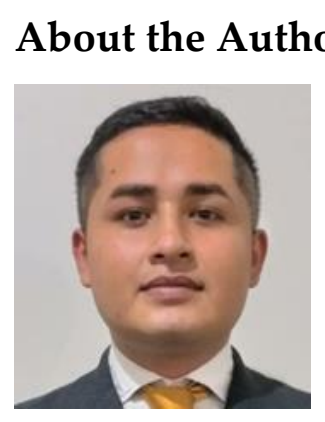

Kennedy Pinargote Rodríguez is a Pre-grade student at the Universidad Laica Eloy Alfaro de Manabí ULEAM in Manta, Ecuador. Lines of research: interculture, human development, language education. kennedyjavi@gmail.com, e1314543511@live.uleam.edu.ec.

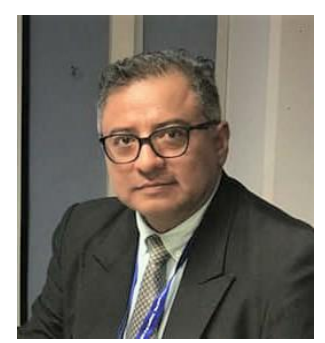

Jhonny Saulo Villafuerte Holguín (PhD) is a doctor in Psycho Didactics and Specific Didactics graduated from the University of the Basque Country, Spain. The leader of the project Comprención Lectora y Escritura Académica: LEA Changing lives of the Faculty of Education Sciences in Laica Eloy Alfaro of the University of Manabí. ULEAM. jhonny.villafuerte@uleam.edu.ec, https://orcid.org/0000-0001-6053$\underline{6307}$

\section{References}

Alata, G., Garcia, O., \& Mercedes, M. (2018). Effective motivation strategy for better performance in oral English language ability in undergraduate program students. Obtained from http://repositorio.utp.edu.pe/handle/UTP/1773

Bautista, M. (2021). The communicative approach and its relationship with the ability of oral expression of the English language in university students. Obtained from https://repositorio.usmp.edu.pe/bitstream/handle/20.500.12727/8217/bautista_sm dp.pdf?sequence $=1 \&$ isAllowed $=\mathrm{y}$

Chen, Z., \& Goh, C. (2016). Teaching oral English in higher education: Challenges to EFL teachers. Teaching in Higher Education. Obtained from http://www.scielo.org.mx/scielo.php?script=sci_arttext\&pid=S166561802016000200006

Cook, G. (2017). Applied Linguistics. Obtained from http://repositorio.puce.edu.ec/bitstream/handle/22000/9150/Tesis\%20\%20Estrateg ias\%20WS\%20junio2015\%20.pdf;sequence=1

Granda, Y. (2017). Application of the "Speak Out" program to improve the oral expression of students of the Language Center of the Agrarian University. Obtained from http://repositorio.ucv.edu.pe/handle/UCV/12811

Hadaway, N., \& Young, T. (2016). Scaffolding oral language development through poetry for students learning English. Obtained from http://www.jstor.org/stable/20204994

Macias, C. (2017). Development of oral expression in English through role play in at-risk students. Obtained from https://intellectum.unisabana.edu.co/handle/10818/31693 
Martinez, R. (2016). Rubrics in the evaluation of the oral expression of the English language in the students of the third years of baccalaureate. Obtained from http://www.dspace.uce.edu.ec/bitstream/25000/12100/1/T-UCE-0010-0882016.pdf

Palacios, P. (2012). How to teach speaking and listening in the classroom. Obtained from https://portalacademico.cch.unam.mx/materiales/libros/pdfs/librocch_hablarescu char.pdf

Reyes, O. (2019). Didactic strategy to develop oral production in the students of the English course. Obtained from http://repositorio.usil.edu.pe/bitstream/USIL/9133/1/2019_Reyes-Carrasco.pdf

Rico-Yate, J., \& Ramírez-Montoya, M. (2016). Development of oral English proficiency through open educational resources. Scielo. Obtained from http://www.scielo.org.mx/scielo.php?script=sci_arttext\&pid=S166561802016000200006

Ruiz, M. (2010). Didactics of the communicative approach. Obtained from https://repositorio.usmp.edu.pe/bitstream/handle/20.500.12727/8217/bautista_sm dp.pdf? sequence $=1 \&$ isAllowed $=y$

Sampieri, R. (2016). Research methodology. Obtained from http://observatorio.epacartagena.gov.co/wpcontent/uploads/2017/08/metodologia-de-la-investigacion-sextaedicion.compressed.pdf

Sanchez, M. (2009). History of foreign language teaching methodology. Obtained from https://repository.unilibre.edu.co/bitstream/handle/10901/15776/Fortalecimiento \%20de\%20la\%20producci\%C3\%B3n\%20oral\%20en\%20ingl\%C3\%A9s\%20a\%20tra $\mathrm{v} \%$ C3\%A9s\%20de\%20recursos\%20TIC.pdf?sequence=1\&isAllowed=y

Wade, K. (2016). Building a second language: constructivism and the teaching of L2. Obtained from http://connection.ebscohost.com/c/articles/48323815/construyendo-unsegundo-idioma-el-constructivismo-y-la-ense-anza-del-12 
Creative Commons licensing terms

Authors will retain the copyright of their published articles agreeing that a Creative Commons Attribution 4.0 International License (CC BY 4.0) terms will be applied to their work. Under the terms of this license, no permission is required from the author(s) or publisher for members of the community to copy, distribute, transmit or adapt the article content, providing a proper, prominent and unambiguous attribution to the authors in a manner that makes clear that the materials are being reused under permission of a Creative Commons License. Views, opinions, and conclusions expressed in this research article are views, opinions and conclusions of the author(s). Open Access Publishing Group and European Journal of English Language Teaching shall not be responsible or answerable for any loss, damage or liability caused in relation to/arising out of conflict of interests, copyright violations and inappropriate or inaccurate use of any kind content related or integrated on the research work. All the published works are meeting the Open Access Publishing requirements and can be freely accessed, shared, modified, distributed and used in educational, commercial and non-commercial purposes under a Creative Commons Attribution 4.0 International License (CC BY 4.0). 